\title{
The unmasking of Pneumocystis jiroveci pneumonia during reversal of immunosuppression: case reports and literature review Alan KL Wu' ${ }^{1}$, Vincent CC Cheng1, Bone SF Tang1, Ivan FN Hung1, Rodney A Lee ${ }^{1}$, David S Hui² and Kwok Y Yuen*1
}

\author{
Address: ${ }^{1}$ Division of Infectious Diseases, Centre of Infection, Queen Mary Hospital, The University of Hong Kong; Hong Kong Special \\ Administrative Region, China and ${ }^{2}$ Division of Pulmonary Medicine, Department of Medicine and Therapeutics, Prince of Wales Hospital, The \\ Chinese University of Hong Kong; Hong Kong Special Administrative Region, China \\ Email: Alan KLWu - alanklwu@yahoo.com; Vincent CC Cheng - cccqmhhk@netvigator.com; Bone SF Tang - bsftang@hkucc.hku.hk; \\ Ivan FN Hung - ivanfn@netvigator.com; Rodney A Lee - ralee@hkucc.hku.hk; David S Hui - dschui@cuhk.edu.hk; \\ Kwok Y Yuen* - kyyuen@hkucc.hku.hk \\ * Corresponding author
}

Published: 09 December 2004

BMC Infectious Diseases 2004, 4:57 doi:10.1/86/147/-2334-4-57
Received: 0I September 2004

Accepted: 09 December 2004

This article is available from: http://www.biomedcentral.com/147I-2334/4/57

(c) 2004 Wu et al; licensee BioMed Central Ltd.

This is an Open Access article distributed under the terms of the Creative Commons Attribution License (http://creativecommons.org/licenses/by/2.0), which permits unrestricted use, distribution, and reproduction in any medium, provided the original work is properly cited.

\begin{abstract}
Background: Pneumocystis jiroveci pneumonia (PCP) is an important opportunistic infection among immunosuppressed patients, especially in those infected with human immunodeficiency virus (HIV). The clinical presentation of PCP in immunosuppressed patients have been well-reported in the literature. However, the clinical importance of PCP manifesting in the setting of an immunorestitution disease (IRD), defined as an acute symptomatic or paradoxical deterioration of a (presumably) preexisting infection, which is temporally related to the recovery of the immune system and is due to immunopathological damage associated with the reversal of immunosuppressive processes, has received relatively little attention until recently.
\end{abstract}

Case presentation: We aim to better define this unique clinical syndrome by reporting two cases of PCP manifesting acutely with respiratory failure during reversal of immunosuppression in non-HIV infected patients, and reviewed the relevant literature. We searched our databases for PCP cases manifesting in the context of IRD according to our predefined case definition, and reviewed the case notes retrospectively. A comprehensive search was performed using the Medline database of the National Library of Medicine for similar cases reported previously in the English literature in October 2003. A total of 28 non-HIV (excluding our present case) and I3 HIV-positive patients with PCP manifesting as immunorestitution disease (IRD) have been reported previously in the literature. During immunorestitution, a consistent rise in the median CD4 lymphocyte count (28/ $\mu \mathrm{L}$ to I25/ $\mu \mathrm{L})$, with a concomitant fall in the median HIV viral load $\left(5.5 \log _{10}\right.$ copies $/ \mathrm{ml}$ to $3.1 \log _{10}$ copies $\left./ \mathrm{ml}\right)$ was observed in HIV-positive patients who developed PCP. A similar upsurge in peripheral lymphocyte count was observed in our patients preceding the development of PCP, as well as in other non-HIV immunosuppressed patients reported in the literature.

Conclusions: PCP manifesting as IRD may be more common than is generally appreciated. Serial monitoring of total lymphocyte or CD4 count could serve as a useful adjunct to facilitate the early diagnosis and pre-emptive treatment of this condition in a wide range of immunosuppressed hosts, especially in the presence of new pulmonary symptoms and/or radiographic abnormalities compatible with the diagnosis. 


\section{Background}

Pneumocystis jiroveci (Pj) (previously known as Pneumocystis carinii f. sp. hominis) was first identified as a pathogen in premature infants suffering from interstitial plasma cell pneumonia in European countries during and after World War II, occasionally occurring in epidemics [1-3]. Since then Pneumocystis pneumonia (PCP) had only been reported sporadically in patients with malignancies and solid organ transplantations until the HIV epidemic [4]. The incidence of PCP increased significantly after the emergence of human immunodeficiency virus (HIV) infection. However, with the identification of CD4 T lymphocyte depletion as an independent risk factor for the development of PCP [5], widespread use of antimicrobial prophylaxis [4], and the introduction of highly active antiretroviral therapy (HAART), there has been a steady decline in the incidence of PCP among HIV-infected patients $[7,8]$.

Nevertheless, with the rising number of patients receiving immunosuppressive therapies for malignancies, solid organ transplantations and autoimmune diseases, PCP has been increasingly recognized in non-HIV immunosuppressed hosts [9-15]. For instance, PCP occurs in 3.4\% to $43 \%$ of solid organ transplant recipients [16], and it is particularly prevalent among those patients who are put on long-term steroids. In a non-HIV immunosuppressed cohort with PCP, the use of steroids was found to be a contributing factor in $87 \%$ of patients [17]. In another similar cohort of immunosuppressed patients, steroids had been administered systemically in 90.5\% within one month before the diagnosis of PCP. Although a median daily dose equivalent to $30 \mathrm{mg}$ of prednisone was administered in most of these patients prior to the development of PCP, up to $25 \%$ had received as little as 16 mg of prednisone daily [18]. Interestingly, PCP has also been reported in patients with endogenous steroid excess due to Cushing's disease $[19,20]$.

Paradoxically, the clinical symptoms of PCP were often unmasked in HIV-negative immunosuppressed patients during the reversal of immunosuppression, often at the time when the dose of steroids was tapered [11,17,21-24], or when the endogenous steroid production was reduced [25-27]. However, serial changes in the absolute lymphocyte count before and during reversal of immunosuppression were not mentioned in these patients. Recently, paradoxical worsening of clinical symptoms and signs of PCP after initiation of HAART has also been reported in HIV-positive patients [28-31]. The onset of clinical deterioration was associated with an upsurge in the CD4 lymphocyte count and a reduction in the HIV viral load [2831]. Tissue damage is thought to occur as a result of immune reconstitution in HIV-positive patients. Here, we report two cases and review the literature on this topic from the perspective of immunorestitution disease.

\section{Case presentation Case I}

This is a fifty-one year old female patient with history of diabetes mellitus and systemic lupus erythematoses (SLE) complicated by lupus nephritis. Although we have included her case in our previous publication [32], we have not reported her clinical details at that time. She was put on prednisolone $30 \mathrm{mg}$ and azathioprine $100 \mathrm{mg}$ daily since end of June and mid-July 2002, respectively. She was admitted to Queen Mary Hospital on $11^{\text {th }}$ August 2002 for investigation of jaundice. Investigations revealed deranged liver function tests with cholestatic pattern. A diagnosis of drug-induced hepatotoxicity was entertained, and azathioprine was stopped after admission. As her autoimmune disease was under control, her steroid dosage was reduced from $25 \mathrm{mg}$ to $15 \mathrm{mg}$ daily within the next 14 days. Her CXR taken on admission was normal.

Soon after her immunosuppressive therapy was tapered, she developed fever and non-productive cough. A repeat CXR performed on $9^{\text {th }}$ Sept revealed new infiltrate over the left mid-zone, suggestive of pneumonia. She was started on intravenous ceftazidime 1 gram eight hourly and oral clarithromycin $500 \mathrm{mg}$ twice daily. Serial CXR performed three days later showed increasing bilateral pulmonary infiltrates and worsening hypoxemia. There was an upsurge of total lymphocyte count from $0.7 \times 10^{9} / \mathrm{L}$ (total white cell count $7.2 \times 10^{9} / \mathrm{L}$ ) at the time of admission to $5.6 \times 10^{9} / \mathrm{L}$ (total white cell count $10.8 \times 10^{9} / \mathrm{L}$ ) at the time of clinical deterioration. Bronchoscopy with transbronchial biopsy performed on the same day revealed Pneumocystitis jiroveci by methenamine sliver stain. Workup for other opportunistic pathogens including cytomegalovirus and aspergillus was negative. She was commenced on intravenous pentamidine $(4 \mathrm{mg} / \mathrm{kg} / \mathrm{day})$ and corticosteroids for severe PCP infection. Despite active treatment she developed progressive respiratory failure and required admission to intensive care unit. She subsequently recovered after a stormy hospital course, and upon discharge from hospital, her total lymphocyte count had returned to her baseline of $0.86 \times 10^{9} / \mathrm{L}$.

\section{Case 2}

A thirty-three year old gentleman initially presented to Prince of Wales Hospital with a diagnosis of SLE/dermatomyositis overlap syndrome. He was treated with steroid and hydroxychloroquine $200 \mathrm{mg}$ twice daily since 1997. He had a flare up of disease in May 1998 with active vasculitis and myositis, for which he was put on prednisolone and azthioprine $50 \mathrm{mg}$ and $100 \mathrm{mg}$ daily respectively. Upon reassessment one month later, disease 
activity was under control, and the dosage of prednisolone was reduced to $45 \mathrm{mg}$ daily.

Twelve day after reducing the immunosuppressive regimen, he was admitted to hospital for treatment of left buttock abscess. The CXR taken on admission was unremarkable. An aspirate of the pus from the lesion grew methicillin-sensitive staphylococcus aureus; he was treated with cloxacillin $1 \mathrm{~g}$ intravenously every 6 hourly, together with incision and drainage of the buttock abscess. In view of the underlying active pyogenic infection, the steroid dosage was rapidly tapered from $45 \mathrm{mg}$ to $15 \mathrm{mg}$ daily within the next four days. However, he was noted to have persistent fever associated with mild unproductive cough. A repeat chest radiograph showed new infiltrates over the right upper and left lower zones, and he was empirically treated with intravenous ceftazidime 1 gram every 8 hours, cloxacillin 1 gram every 6 hours and netimicin 100 mg every 8 hours. As there was no clinical response after 5 days of treatment, bronchoscopy and bronchoalveolar lavage (BAL) was performed, which was positive for Pneumocystis jiroveci. Investigation for the presence of co-existing opportunistic pathogens such as cytomegalovirus and aspergillus was negative. On the day after bronchoscopy, he was commenced on intravenous cotrimoxazole 1.3 grams every 6 hours. He remained stable initially with fever on downward trend. However, on the $3^{\text {rd }}$ day of treatment, he developed sudden desaturation with resurgence of high fever, and required supplemental oxygen therapy. Repeat chest radiograph showed increased perihilar hazziness in both lung fields. There was also an upsurge of total lymphocyte count from $0.6 \times 10^{9} / \mathrm{L}$ (total white cell count $11.2 \times 10^{9} / \mathrm{L}$ ) on admission, to $1.3 \times 10^{9} /$ L (total white cell count $10.4 \times 10^{9} / \mathrm{L}$ ) at the time of clinical deterioration. He was treated with high dose prednisolone ( $80 \mathrm{mg}$ daily), and his condition improved promptly afterwards. He was subsequently discharged, and on follow up at the clinic one month later, his total lymphocyte count had returned to his baseline level of 0.6 $\times 10^{9} / \mathrm{L}$.

Immunorestitution disease (IRD) has been described in both HIV and non-HIV immunosuppressed hosts previously [27-31]. In the setting of PCP, it is defined as an acute symptomatic presentation of the disease that is related temporally to the recovery of the immune system, associated with reversal of immunosuppressive processes such as reduction in the dosage of corticosteroids and/or cytotoxic agents or a reduction of HIV viral load due to HAART, which results in the development of immunopathological damage. The preexisting microbial infection could be either asymptomatic or mildly symptomatic. Using this case definition, we attempted to review the English literature for other reported cases of PCP manifesting as IRD. The English-language literature
(1966 - 2003) was searched in the Medline database of the National Library of Medicine in October 2003. The keywords "Pneumocystis carinii", "Pneumocystis jiroveci", "HIV", immunosuppression", "immunosuppressive", "steroid", and "corticosteroid" were used to select cases. All the case reports and case series with clinical details were included in this study if they fulfilled the above definition of IRD. When appropriate, the cited bibliographies were also retrieved for further analysis. As for statistical analysis, we used the Wilcoxon Signed Rank test, a nonparametric test for comparing paired samples, to analyze the serial changes in lymphocyte counts and HIV viral loads before and during the development of IRD. A twotailed p-value of less than 0.05 was considered significant. All statistical analyses were performed using SPSS version 11.5 for Windows.

Including our present case, a total of 29 cases of PCP in non-HIV immunosuppressed hosts fulfilling our definition of IRD have been reported in the literature (table 1) $[22-27,32]$. There were altogether 13 males and 8 females, with a median age of 38 years (range 2 to 75 years). The age and sex were not mentioned in 8 cases. Their underlying immunosuppressive conditions included solid organ tumours (13 cases), haematological diseases (8), autoimmune diseases (4), endogenous Cushing's disease (3), and a solid organ transplant recipient (1). All patients had received steroids or had excessive endogenous steroid production, whereas 18 (62.1\%) of them had concomitant cytotoxic therapy for the underlying diseases. The median duration between steroid tapering and clinical manifestations of PCP was 21 days (range 1 to 83 days). Steroids were completely withdrawn at a median of 7.5 days (range 1 to 21 days) before the onset of symptoms in eight patients. Serial lymphocyte counts were only available in eight patients. An upsurge of the absolute lymphocyte counts was observed from the time of reduction of immunosuppression (median $300 / \mu \mathrm{L}$, range 290 to $600 / \mu \mathrm{L}$ at baseline) to the time of occurrence of IRD (median 1200/ $\mu \mathrm{L}$, range 600 to $5620 / \mu \mathrm{L}$ ); the median increase in total lymphocyte count was $800 / \mu \mathrm{L}$, with a range of 300 to $4880 / \mu \mathrm{L}$. Comparing the lymphocyte counts before and after reversal of immunosuppressive therapy, the difference was statistically significant (Wilcoxon Signed Rank Test for paired samples; $\mathrm{p}=0.012$ ). In addition to our patient, reintroduction or increasing doses of steroids were required in $7(53.8 \%)$ of 13 patients in the acute management of PCP in the literature, at the time when they developed clinical deterioration during antimicrobial therapy [24-27]. Seven (53.8\%) of 13 cases had respiratory failure requiring mechanical ventilation. Among these 29 cases, 13 (44.8\%) subsequently died of PCP.

Among HIV-positive patients, 13 cases with newly diagnosed PCP were reported in the literature, in which IRD 
Table I: Summary of literature reported cases of HIV-negative immunocompromised patients with PCP manifested as IRD

\begin{tabular}{|c|c|c|c|c|c|}
\hline Case [Ref.] & Sex/Age (years) & Underlying disease (s) & $\begin{array}{l}\text { Reduction of IS level } \\
\text { before symptoms } \\
\text { onset of IRD }\end{array}$ & $\begin{array}{l}\text { Symptoms \& signs at IRD; change of } \\
\text { lymphocyte count before \& during } \\
\text { IRD (if mentioned) }\end{array}$ & $\begin{array}{l}\text { Treatment, clinical } \\
\text { progress \& outcome }\end{array}$ \\
\hline $\mathrm{I}-7$ [22] & $\begin{array}{l}\text { M/F: } 4: 3 \text { Median } \\
\text { age } 12 \text {, range } 2- \\
25\end{array}$ & $\begin{array}{l}\text { Acute leukemia in } \\
\text { remission (4), acute } \\
\text { leukemia in relapse } \\
\text { (1), Hodgkin's disease } \\
\text { (1), embryonal } \\
\text { carcinoma of testes } \\
\text { (I) }\end{array}$ & $\begin{array}{l}\mathrm{P} \downarrow \text { from } 100 \mathrm{mg} \text { to } \\
40 \text { mg over } 3 \text { weeks in } \\
\text { I patients; } \\
\text { In another } 6 \text { patients, } \\
\text { P stopped in a median } \\
\text { of I0.5 days, range (I- } \\
21 \text { days) before } \\
\text { symptoms onset }\end{array}$ & NM & Died (5) \& survived (2) \\
\hline $8-15$ [23] & NM & $\begin{array}{l}\text { Primary brain tumour } \\
\text { (8) }\end{array}$ & $\begin{array}{l}\text { Dexa } \downarrow \text { over a median } \\
\text { of } 12.5 \text { days, range ( } 1- \\
63 \text { days) }\end{array}$ & $\begin{array}{l}\text { Fever (4), nonproductive cough (4), } \\
\text { productive cough ( } 2 \text { ), dyspnoea (7), } \\
\text { chest pain (4); CXR: bilateral } \\
\text { infiltrates (3), diffuse infiltrates (3), } \\
\text { focal infiltrates ( } 1 \text { ), clear (I) }\end{array}$ & Died (3) \& survived (5) \\
\hline $16[24]$ & $M / 55$ & $\begin{array}{l}\text { Primary brain tumour } \\
\text { (glioblastoma } \\
\text { multiforme) }\end{array}$ & $\begin{array}{l}\text { Dexa } \downarrow \text { from } 16 \mathrm{mg} \\
\text { qd to } 2 \mathrm{mg} \text { qd over } 8 \\
\text { weeks }\end{array}$ & $\begin{array}{l}\text { Intermittent fever, nonproductive } \\
\text { cough, progressive dyspnoea; } \mathrm{CXR} \text { : } \\
\text { bilateral interstitial infiltrates; } \mathrm{PaO}_{2} \\
\text { (RA): } 51 \mathrm{mmHg}\end{array}$ & $\begin{array}{l}\text { Treated with intravenous } \\
\text { cotrimoxazole; survived }\end{array}$ \\
\hline $17[24]$ & $\mathrm{F} / 74$ & $\begin{array}{l}\text { Primary brain tumour } \\
\text { (meningioma) }\end{array}$ & $\begin{array}{l}\text { Dexa } \downarrow \text { from } 12 \mathrm{mg} \\
\text { qd to } 4 \mathrm{mg} \text { qd over } 2 \\
\text { weeks }\end{array}$ & $\begin{array}{l}\text { Intermittent fever, nonproductive } \\
\text { cough; } \mathrm{CXR} \text { : bilateral interstitial } \\
\text { infiltrates; } \mathrm{PaO}_{2}(\mathrm{RA}): 45 \mathrm{mmHg}\end{array}$ & $\begin{array}{l}\text { Treated with intravenous } \\
\text { cotrimoxazole; survived }\end{array}$ \\
\hline $18[24]$ & $M / 50$ & $\begin{array}{l}\text { Primary brain tumour } \\
\text { (astrocytoma) }\end{array}$ & $\begin{array}{l}\text { Dexa } \downarrow \text { from } 16 \mathrm{mg} \\
\text { qd to I mg qd over } 8 \\
\text { weeks }\end{array}$ & $\begin{array}{l}\text { Fever, nonproductive cough, } \\
\text { dyspnoea; } \mathrm{CXR} \text { : bilateral interstitial } \\
\text { infiltrates; } \mathrm{PaO}_{2}(\mathrm{RA}): 73 \mathrm{mmHg}\end{array}$ & $\begin{array}{l}\text { Treated with intravenous } \\
\text { cotrimoxazole; } \\
\text { mechanical ventilation; } \\
\text { survived }\end{array}$ \\
\hline 19 [24] & $M / 75$ & $\begin{array}{l}\text { Primary brain tumour } \\
\text { (glioblastoma } \\
\text { multiforme) }\end{array}$ & $\begin{array}{l}\text { Dexa } \downarrow \text { from } 16 \mathrm{mg} \\
\text { qd to } 4 \mathrm{mg} \text { qd over } 6 \\
\text { weeks }\end{array}$ & $\begin{array}{l}\text { Fever, nonproductive cough, bloody } \\
\text { diarrhoea; } \mathrm{CXR} \text { : clear; } \mathrm{PaO}_{2}(\mathrm{RA}) \text { : } \\
89 \mathrm{mmHg}\end{array}$ & $\begin{array}{l}\text { Treated with intravenous } \\
\text { cotrimoxazole; survived }\end{array}$ \\
\hline $20[25]$ & $M / 24$ & $\begin{array}{l}\text { ACTH- producing } \\
\text { metastatic bronchial } \\
\text { carcinoid }\end{array}$ & $\begin{array}{l}\text { Serum cortisol } \downarrow \text { from } \\
138 \mathrm{pg} / \mathrm{ml} \text { to } 18 \mathrm{pg} / \mathrm{ml} \\
\text { over } 54 \text { days }\end{array}$ & $\begin{array}{l}\text { Fever, nonproductive cough, } \\
\text { weakness, sweats; } \mathrm{CXR} \text { : bilateral } \\
\text { fluffy infiltrates; } \mathrm{PaO}_{2}(\mathrm{RA}): 40 \\
\mathrm{mmHg}\end{array}$ & $\begin{array}{l}\text { Treated with intravenous } \\
\text { cotrimoxazole; } \\
\text { mechanical ventilation; } \\
\text { died of malignancy }\end{array}$ \\
\hline $21[26]$ & $F / 38$ & $\begin{array}{l}\text { Endogenous Cushing's } \\
\text { syndrome }\end{array}$ & $\begin{array}{l}\text { Metyrapone } 750 \mathrm{mg} \\
\text { qd added I day before } \\
\text { symptoms onset }\end{array}$ & $\begin{array}{l}\text { Productive cough, dyspnoea; CXR: } \\
\text { right lower upper lobe infiltrates; } \\
\mathrm{PaO}_{2}(\mathrm{RA}): 31 \mathrm{mmHg}\end{array}$ & $\begin{array}{l}\text { Treated with intravenous } \\
\text { cotrimoxazole; } \\
\text { mechanical ventilation; } \\
\text { died }\end{array}$ \\
\hline $22-28$ [32] & $\begin{array}{l}\text { M/F 4:3 Mean } \\
\text { (SD) age } 53.1 \\
\text { (13.6) }\end{array}$ & $\begin{array}{l}\text { ITP (2), GN (2), } \\
\text { bullous pemphigoid } \\
\text { (I), endogenous } \\
\text { Cushing's syndrome } \\
\text { (I), and renal } \\
\text { transplantation (I) }\end{array}$ & $\begin{array}{l}\text { Reduction of steroid } \\
\text { but details of tailing } \\
\text { regimen was not } \\
\text { mentioned }\end{array}$ & $\begin{array}{l}\text { An upsurge of lymphocyte counts } \\
\text { from the reduction of } \\
\text { immunosuppression (median } 300 / \\
\mu \mathrm{L} \text {, range } 290 \text { to } 740 / \mu \mathrm{L} \text { ) to the } \\
\text { onset of IRD (median I500/ } \mu \mathrm{L} \text {, } \\
\text { range } 600 \text { to } 5620 / \mu \mathrm{L} \text { ) }\end{array}$ & $\begin{array}{l}\text { Treated with steroid as } \\
\text { anti-PJP therapy in } 7 \\
(100 \%) \text {; mechanical } \\
\text { ventilation in } 6(85.7 \%) \text {, } \\
\text { died in } 3(42.9 \%)\end{array}$ \\
\hline 29 & $\begin{array}{l}\text { M/33 (Our } \\
\text { patient) }\end{array}$ & $\begin{array}{l}\text { Systemic lupus } \\
\text { erythematosus/ } \\
\text { dermato-myositis } \\
\text { overlapping syndrome }\end{array}$ & $\begin{array}{l}\mathrm{P} \downarrow \text { from } 45 \mathrm{mg} \text { to } \mathrm{I} 5 \\
\mathrm{mg} \text { over } 4 \text { days }\end{array}$ & $\begin{array}{l}\text { Fever, dyspnoea; CXR: increased } \\
\text { perihilar infilitrates; lymphocyte } \\
\text { count increased from } 600 \text { to } 1300 / \\
\mu \mathrm{L}\end{array}$ & $\begin{array}{l}\text { Treated with intravenous } \\
\text { cotrimoxazole and } \\
\text { steroid; survived }\end{array}$ \\
\hline
\end{tabular}

Note. Aza, azathioprine; CXR, chest radiograph; Dexa, dexamethasone; IRD, immunorestitution disease; ITP, immune thrombocytopenia purpura; IS, immunosuppression; GN, glomerulonephritis; P, prednisolone; PCP, Pneumocystis jiroveci pneumonia; RA, room air.

occurred shortly after the introduction of HAART (table 2) [28-31]. Seven (53.8\%) out of 13 cases received steroids as adjunctive therapy in addition to antimicrobials. HAART was given in all cases at a median 18 days (range 1 to 35 days) after the initiation of treatment for PCP. During IRD, recurrence of fever (100\%), dyspnoea $(100 \%)$, and paradoxical worsening of pulmonary infiltrates $(58.3 \%)$ were observed in these patients [28-31]. IRD occurred at a median of 14 days (range 5 to 17 days) after HAART. An upsurge of the CD4 lymphocyte count was observed before (median $28 / \mu \mathrm{L}$, range 4 to $290 / \mu \mathrm{L}$ ) and during IRD (median $125 / \mu \mathrm{L}$, range 30 to $564 / \mu \mathrm{L}$ ); this was associated with a concomitant reduction of the median HIV viral load from $5.5 \log _{10}$ copies/ml (range 5.0 to $5.9 \log _{10}$ copies $/ \mathrm{ml}$ ) to $3.1 \log _{10}$ copies/ml (range 2.9 to $4.5 \log _{10}$ copies/ml) before and during IRD respectively, and the 
Table 2: Summary of literature reported cases of HIV-positive patients with IRD to PCP after HAART

\begin{tabular}{|c|c|c|c|c|c|c|c|c|}
\hline $\begin{array}{l}\text { Case [Ref.] } \\
\text { Sex/Age }\end{array}$ & $\begin{array}{l}\text { CD4 }(/ \mu \mathrm{L}) \& \\
\text { HIVRNA } \\
\text { (log }{ }_{10} \text { copies/ } \\
\text { ml) before } \\
\text { HAART }\end{array}$ & $\begin{array}{l}\text { Therapy of } \\
\text { PJP \& HAART } \\
\text { regimen }\end{array}$ & $\begin{array}{l}\text { Day of } \\
\text { HAART after } \\
\text { initiation of } \\
\text { PCP } \\
\text { treatment }\end{array}$ & $\begin{array}{l}\text { Symptoms \& signs } \\
\text { during IRD }\end{array}$ & $\begin{array}{l}\text { Day of } \\
\text { IRD after } \\
\text { initiation } \\
\text { of HAART }\end{array}$ & $\begin{array}{l}\text { Day of } \\
\text { steroid } \\
\text { withdrawal } \\
\text { before the } \\
\text { onset of IRD }\end{array}$ & $\begin{array}{l}\text { CD4 }(/ \mu L) \& \\
\text { HIVRNA } \\
\text { (log }{ }_{10} \text { copies/ } \\
\text { ml) during } \\
\text { IRD }\end{array}$ & $\begin{array}{l}\text { Therapy of } \\
\text { IRD \& clinical } \\
\text { outcome }\end{array}$ \\
\hline I [28] M/37 & $7 \& 5.1$ & $\begin{array}{l}\text { Cotrimoxazol } \\
\text { e \& MP; } \\
\text { zidovudine, } \\
\text { lamivudine, \& } \\
\text { indinavir }\end{array}$ & 16 days & $\begin{array}{l}\text { High fever, acute } \\
\text { respiratory failure; } \\
\text { CXR: patchy } \\
\text { alveolar opacities in } \\
\text { both upper lobes }\end{array}$ & 7 days & 7 days & 38 \& UD & $\begin{array}{l}\text { Restart cotri- } \\
\text { moxazole \& } \\
\text { stop HAART; } \\
\text { survived }\end{array}$ \\
\hline 2 [28] M/47 & $28 \& 5.0$ & $\begin{array}{l}\text { Cotrimoxazol } \\
\text { e \& MP, then } \\
\text { aerosolized } \\
\text { pentamidine; } \\
\text { viramune, } \\
\text { stavudine, \& } \\
\text { didanosine }\end{array}$ & I day & $\begin{array}{l}\text { High fever, acute } \\
\text { respiratory failure } \\
\text { requiring intubation; } \\
\text { CXR: diffuse } \\
\text { alveolar opacities }\end{array}$ & 17 days & 2 days & $40 \& 4.5$ & $\begin{array}{l}\text { Restart MP \& } \\
\text { stop HAART; } \\
\text { survived }\end{array}$ \\
\hline 3 [28] F/50 & $230 \& 5.8$ & $\begin{array}{l}\text { Cotrimoxazol } \\
\text { e \& MP; } \\
\text { zidovudine, } \\
\text { lamivudine, \& } \\
\text { indinavir }\end{array}$ & 16 days & $\begin{array}{l}\text { High fever, acute } \\
\text { respiratory failure; } \\
\text { CXR: patchy } \\
\text { alveolar opacities in } \\
\text { both upper lobes }\end{array}$ & 7 days & 7 days & $564 \& 3.1$ & $\begin{array}{l}\text { Start } \\
\text { Atovaquone, } \\
\text { aerosolized } \\
\text { pentamidine, } \\
\text { \& steroid; } \\
\text { survived }\end{array}$ \\
\hline $\begin{array}{l}4-6[29] \\
N M\end{array}$ & $\begin{array}{l}26 \& 5.5 \\
\text { (median) }\end{array}$ & $\begin{array}{l}\text { Cotrimoxazol } \\
\text { e \& high dose } \\
\text { steroid; NM }\end{array}$ & $\begin{array}{l}15-18 \text { days } \\
\text { (range) }\end{array}$ & $\begin{array}{l}\text { Swinging fever, acute } \\
\text { respiratory failure, \& } \\
\text { radiological } \\
\text { deterioration }\end{array}$ & $\begin{array}{l}5 \text { days } \\
\text { (median); } \\
\text { 3-I7 days } \\
\text { (range) }\end{array}$ & NM & $\begin{array}{l}62 \& 2.87 \\
\text { (median) }\end{array}$ & $\begin{array}{l}\text { Re- } \\
\text { introducing } \\
\text { high dose } \\
\text { steroids \& } \\
\text { alternative } \\
\text { PJP therapy; } \\
\text { all three } \\
\text { patients } \\
\text { survived }\end{array}$ \\
\hline 7 [30] M/38 & $4 \& 5.5$ & $\begin{array}{l}\text { Atovaquone; } \\
\text { didanosine, } \\
\text { efavirenz, } \\
\text { nelfinavir, \& } \\
\text { stavudine }\end{array}$ & 35 days & $\begin{array}{l}\text { Fever, cough, } \\
\text { dyspnoea, \& night } \\
\text { sweats; CXR: } \\
\text { bilateral mid \& lower } \\
\text { zone airspace } \\
\text { shadow }\end{array}$ & 14 days & NA & $125 \& 3.6$ & $\begin{array}{l}\text { Intravenous } \\
\text { pentamidine } \\
\& \\
\text { hydrocortiso } \\
\text { ne; survived }\end{array}$ \\
\hline 8 [30] NM & $70 \& N M$ & $\begin{array}{l}\text { Cotrimoxazol } \\
\text { e; zidovudine }\end{array}$ & & & & & 182 \& NM & $\begin{array}{l}\text { Cotrimoxazol } \\
\text { e; survived }\end{array}$ \\
\hline 9 [30] NM & $10 \& N M$ & $\begin{array}{l}\text { Cotrimoxazol } \\
\text { e; zidovudine }\end{array}$ & $\begin{array}{l}21 \text { days } \\
\text { (median) 17- } \\
24 \text { days } \\
\text { (range) }\end{array}$ & $\begin{array}{l}\text { Fever, dyspnoea, } \\
\text { with or without } \\
\text { cough }\end{array}$ & $\begin{array}{l}\text { I5 days } \\
\text { (median) } \\
\text { 5-30 days } \\
\text { (range) }\end{array}$ & NM & $30 \& N M$ & $\begin{array}{l}\text { Supportive } \\
\text { therapy }\end{array}$ \\
\hline 10 [30] NM & $216 \& N M$ & $\begin{array}{l}\text { Cotrimoxazol } \\
\text { e \& steroid; } \\
\text { zidovudine }\end{array}$ & & & & & $340 \&$ NM & $\begin{array}{l}\text { Cotrimoxazol } \\
\text { e \& steroid }\end{array}$ \\
\hline II [30] NM & $290 \& N M$ & $\begin{array}{l}\text { Cotrimoxazol } \\
\text { e; zidovudine, } \\
\text { \& didanosine }\end{array}$ & & & & & $430 \&$ NM & $\begin{array}{l}\text { Cotrimoxazol } \\
\mathrm{e}\end{array}$ \\
\hline 12 [30] NM & $60 \& N M$ & $\begin{array}{l}\text { Cotrimoxazol } \\
\text { e; zidovudine }\end{array}$ & & & & & $130 \&$ NM & $\begin{array}{l}\text { Supportive } \\
\text { therapy }\end{array}$ \\
\hline $\begin{array}{l}13[3 \mid] \mathrm{M} / \\
34\end{array}$ & $46 \&>5.9$ & $\begin{array}{l}\text { Cotrimoxazol } \\
\text { e; zidovudine, } \\
\text { lamivudine, } \\
\text { lopinavir- } \\
\text { ritonavir }\end{array}$ & 18 days & $\begin{array}{l}\text { Recurrent fever, } \\
\text { chest discomfort, } \\
\text { cough, \& dyspneoa; } \\
\text { CXR showed diffuse } \\
\text { bilateral } \\
\text { reticulonodular } \\
\text { infiltrates }\end{array}$ & I4 days & NA & $435 \& 4.5$ & $\begin{array}{l}\text { Cotrimoxazol } \\
\text { e (pro- } \\
\text { phylactic } \\
\text { dose) \& } \\
\text { keeping } \\
\text { HAART; } \\
\text { survived }\end{array}$ \\
\hline
\end{tabular}

Note. CXR, chest radiograph; HAART, highly active antiretroviral therapy; IRD, immunorestitution disease; MP, methylprednisolone; NA, not applicable; NM, not mentioned; PCP, pneumocystis jiroveci pneumonia 
differences observed in both the CD4 counts and viral loads before and during IRD reached statistical significance (Wilcoxon Signed Rank Test for related samples; $\mathrm{p}=$ 0.001 and 0.017 , respectively). Antimicrobials, steroids, or both for PCP were reintroduced for IRD in 4, 1, and 6 cases respectively. Only 2 cases were treated conservatively. One case required mechanical ventilation for severe respiratory distress. None of the patients died.

PCP manifesting as a form of IRD is not a rare phenomenon. As shown in our previous study, it happens in 7 out of $10(70 \%)$ of HIV-negative immunosuppressed hosts infected with $\mathrm{Pj}$ [32]. However, the diagnosis of PCP is usually delayed in this group of patients because of atypical presentation. In this clinical setting, PCP manifesting as IRD often runs an acute and fulminant course, with nonspecific lesions on chest radiographs, and high absolute lymphocyte counts [32]. In our own reported series, despite the administration of steroid therapy to suppress the immunopathological damage, more than $80 \%$ of patients developed acute respiratory failure and required mechanical ventilation. Patients who developed PCP during reversal of immunosuppressive therapy in our series tended to be older, and this might partially explain the increased mortality observed in this group [32].

Rapid reduction of immunosuppressive therapy such as steroids has been implicated as a predisposing factor for the development of PCP in HIV-negative patients $[11,17,23,24]$. In one study, PCP occurred in $79(70 \%)$ of 113 patients during steroid tapering [17]. Another study suggested that $8(72.2 \%)$ out of 11 episodes of PCP developed when steroid therapy was tapered [23]. A subsequent study also demonstrated that $43 \%$ of patients had a rapid reduction of steroid dosing before the clinical manifestations of PCP [11]. A similar experience was reported in children, and 17 (89.5\%) out of 19 children were diagnosed to have PCP during steroid tapering according to a previous report [21]. Another series revealed that 7 of 11 patients experienced acutely symptomatic PCP when the dose of steroids was decreased or terminated 5 days to 3 weeks before the diagnosis of PCP [22]. However, all these cases were not analyzed from a perspective of IRD. Serial changes of the absolute lymphocyte counts or their subsets were either not noted or reported [11,17,21-24]. Hence we have not included these cases for further analysis in this review.

Among HIV positive patients, PCP manifesting acutely during the initiation anti-retroviral therapy is a well-recognized phenomenon. The underlying immunopathological nature of this condition, which is reminiscent to IRD occurring in non-HIV infected patients, has been confirmed by histological examination of the lungs and transbronchial biopsy specimens, which demonstrated mixed inflammatory infiltrates including macrophages, neutrophils, lymphocytes, and plasma cells. Almost all infiltrating lymphocytes found in the tissues were of the T cell lineage, shown by immunophenotyping to be predominantly CD4 and CD8 cells [28]. In another study [30], the BAL fluid obtained from one of six patients with an IRDtype presentation of PCP was analyzed. Infiltration of predominantly CD4 and CD8 lymphocytes with the proliferative marker (Ki67) and perforin-positive cell were seen in the BAL specimen. Therefore, it is likely that the phagocytosed $\mathrm{Pj}$ is presented by alveolar macrophage to T cells, which trigger the inflammatory response [30].

In our own experience, as well as from the review of published literature, it appears that a surge of absolute lymphocyte count, especially the CD4 lymphocyte count in HIV-positive patients, could potentially act as a surrogate marker for immunopathological damage during IRD in both HIV-negative and HIV-positive patients. In our recent publication [32], 7 out of 10 non-HIV immunosuppressed patients demonstrated a consistent rise in the absolute lymphocyte count during tapering of immunosuppression prior to the onset of symptomatic PCP. In this group of patients, the surge in lymphocyte count is likely the result of withdrawal of lymphocytotoxic immunosuppressants such as corticosteroids. Similarly, a rising trend of the CD4 lymphocyte count, consistent with immune reconstitution after HAART, was also observed in 13 HIV-positive cases before and during the development of symptomatic PCP [28-31]. In fact, an upsurge in the absolute lymphocyte count has been shown to be a marker of IRD in our previous publications involving viral and tuberculous infections [33-36]. However, it must be emphasized that the number of circulating lymphocytes may not always correlate with their number in the affected tissues or their in vivo functional activity. This can be exemplified by a case of PCP occurring during steroid withdrawal, in which the lymphocyte counts surged to a very high level and then rapidly dropped to a low level within one day. The migration of lymphocytes from the circulation to tissue might explain this rapid drop in lymphocyte count and the resulting immunopathological damage [27]. In the future, further studies on lymphocyte subsets and cytokine profiles of susceptible hosts during the development of IRD should be performed to elucidate the underlying immunopathological mechanisms behind this interesting phenomenon.

From the result of this review, it appears that HIV-positive patients with PCP are at risk of clinical deterioration due to IRD if HAART therapy is started within 1 to 2 weeks after the initiation of treatment for PCP (table 2). With a better understanding of the pathogenetic mechanisms resulting in IRD, we may be able to prevent the occurrence of IRD by delaying the initiation of HAART in HIV-posi- 
tive patients with PCP. However, in non-HIV immunosuppressed patients, it is even more important to recognize the atypical presentations of PCP in the context of IRD. Since the clinical and/or radiological features alone may not be sufficient for diagnosis, analysis of serial changes in lymphocyte counts in patients undergoing a reduction of immunosuppression can alert the clinician to the possibility of IRD due to occult pathogens such as $\mathrm{Pj}$. To prevent IRD in non-HIV immunosuppressed patients, the use of prophylactic antibiotics against $\mathrm{Pj}$ to reduce the microbial load in selected patients remains an important issue. Recently, a multi-center study showed that the CD4 lymphocyte count may be a useful marker to monitor the risk of development of PCP in non-HIV immunosuppressed hosts [37], and patients with low CD4 lymphocyte counts of less than 300 or 400 may require prophylaxis. In fact, asymptomatic colonization of $\mathrm{Pj}$ has been demonstrated in HIV-negative patients when the CD4 lymphocyte count was less than 400 [38]. Nested polymerase chain reaction (PCR) identified a significant percentage of clinically silent $\mathrm{Pj}$ colonization in $20 \%$ of non-HIV immunosuppressed patients [39]. Therefore, early detection of asymptomatic infection of $\mathrm{Pj}$ in blood and respiratory specimens before, and during intense immunosuppression may enable selection of cases for pre-emptive treatment of $\mathrm{Pj}$ infection in order to prevent the development of IRD during reversal of immunosuppression $[40,41]$.

\section{Conclusions}

PCP occurring in the context of IRD is not a rare phenomenon and is likely to be under-reported in the literature. In this setting, it may be more common for PCP to manifest acutely with a fulminant clinical course. Clinicians caring for immunosuppressed patients should be alert to this unique phenomenon so as to initiate timely and appropriate investigations and treatment for their patients. Serial monitoring of lymphocyte count, or if possible CD4 count, could serve as a useful adjunct to facilitate the diagnosis and management of this condition in a wide range of immunosuppressed hosts, especially in the presence of new pulmonary symptoms and/or radiographic abnormalities compatible with the diagnosis.

\section{Competing interests}

The author(s) declare that they have no competing interests.

\section{Authors' contributions}

RAL and DSH were involved in the clinical evaluation and treatment of patients. BST and IFH helped with literature searching and review. AKW and VCC drafted and refined the manuscript. KYY conceived the study, participated in its design and coordination, and supervised the preparation of the manuscript. All authors have read and approved the final draft of the manuscript before submission.

\section{References}

I. Gajdusek DC: Pneumocystis carinii; etiologic agent of interstitial plasma cell pneumonia of premature and young infants. Pediatrics 1957, 19:543-65.

2. Dutz W: Pneumocystis carinii pneumonia. Pathol Annu 1970, 5:309-4I.

3. Burke BA, Good RA: Pneumocystis carinii infection. Medicine (Baltimore) 1973, 52:23-51.

4. Hughes WT: Current issues in the epidemiology, transmission, and reactivation of Pneumocystis carinii. Semin Respir Infect 1998, 13:283-8.

5. Masur H, Ognibene FP, Yarchoan R, Shelhamer JH, Baird BF, Travis W, Suffredini AF, Deyton L, Kovacs JA, Falloon J: CD4 counts as predictors of opportunistic pneumonias in human immunodeficiency virus (HIV) infection. Ann Intern Med 1989, I | I:223-31.

6. Chien SM, Rawji M, Mintz S, Rachlis A, Chan CK: Changes in hospital admissions pattern in patients with human immunodeficiency virus infection in the era of Pneumocystis carinii prophylaxis. Chest 1992, 102:1035-9.

7. Palella FJ Jr, Delaney KM, Moorman AC, Loveless MO, Fuhrer J, Satten GA, Aschman DJ, Holmberg SD: Declining morbidity and mortality among patients with advanced human immunodeficiency virus infection. HIV Outpatient Study Investigators. N Engl J Med 1998, 338:853-60.

8. Pulvirenti J, Herrera P, Venkataraman P, Ahmed N: Pneumocystis carinii pneumonia in HIV-infected patients in the HAART era. AIDS Patient Care STDS 2003, I 7:26 I-5.

9. Sepkowitz KA: Pneumocystis carinii pneumonia in patients without AIDS. Clin Infect Dis 1993:S4I6-22.

10. Varthalitis I, Aoun M, Daneau D, Meunier F: Pneumocystis carinii pneumonia in patients with cancer. An increasing incidence. Cancer 1993, 7 1:481-5.

II. Arend SM, Kroon FP, van't Wout JW: Pneumocystis carinii pneumonia in patients without AIDS, 1980 through I993. An analysis of 78 cases. Arch Intern Med 1995, I 55:2436-4I.

12. Lufft V, Kliem V, Behrend M, Pichlmayr R, Koch KM, Brunkhorst R: Incidence of Pneumocystis carinii pneumonia after renal transplantation. Impact of immunosuppression. Transplantation 1996, 62:421-3.

13. Kulke MH, Vance EA: Pneumocystis carinii pneumonia in patients receiving chemotherapy for breast cancer. Clin Infect Dis 1997, 25:215-8.

14. Bachelez H, Schremmer B, Cadranel J, Mouly F, Sarfati C, Agbalika F, Schlemmer B, Mayaud CM, Dubertret L: Fulminant Pneumocystis carinii pneumonia in 4 patients with dermatomyositis. Arch Intern Med 1997, I 57:1501-3.

I5. Varela JM, Fernandez-Alonso J, Wichmann I, Calderon EJ: Pneumocystis carinii investigation in patients with Wegener's granulomatosis. Br J Rheumatol 1998, 37:349-50.

16. Sepkowitz KA, Brown AE, Armstrong D: Pneumocystis carinii pneumonia without acquired immunodeficiency syndrome. More patients, same risk. Arch Intern Med 1995, I 55: I I25-8.

17. Sepkowitz KA, Brown AE, Telzak EE, Gottlieb S, Armstrong D: Pneumocystis carinii pneumonia among patients without AIDS at a cancer hospital. JAMA 1992, 267:832-7.

18. Yale $\mathrm{SH}$, Limper $\mathrm{AH}$ : Pneumocystis carinii pneumonia in patients without acquired immunodeficiency syndrome: associated illness and prior corticosteroid therapy. Mayo Clin Proc 1996, 7 I:5-13.

19. Anthony LB, Greco FA: Pneumocystis carinii pneumonia: a complication of Cushing's syndrome. Ann Intern Med I98I, 94:488-9.

20. Graham BS, Tucker WS Jr: Opportunistic infections in endogenous Cushing's syndrome. Ann Intern Med 1984, I 0 I:334-8.

21. Johnson HD, Johnson WW: Pneumocystic carinii pneumonia in children with cancer. Diagnosis and treatment. JAMA 1970, 21 4: 1067-73.

22. Singer C, Armstrong D, Rosen PP, Schottenfeld D: Pneumocystis carinii pneumonia: a cluster of eleven cases. Ann Intern Med 1975, 82:772-7. 
23. Henson JW, Jalaj JK, Walker RW, Stover DE, Fels AO: Pneumocystis carinii pneumonia in patients with primary brain tumors. Arch Neurol 1991, 48:406-9.

24. Slivka A, Wen PY, Shea WM, Loeffler JS: Pneumocystis carinii pneumonia during steroid taper in patients with primary brain tumors. Am J Med 1993, 94:216-9.

25. Natale RB, Yagoda A, Brown A, Singer C, Stover D, Bajorunas D: Combined Pneumocystis carinii and Nocardia asteroides pneumonitis in a patient with an ACTH-producing carcinoid. Cancer 198I, 47:2933-5.

26. Fulkerson WJ, Newman JH: Endogenous Cushing's syndrome complicated by Pneumocystis carinii pneumonia. Am Rev Respir Dis 1984, 129: 188-9.

27. Cheng VC, Yuen KY, Chan WM, Wong SS, Ma ES, Chan RM: Immunorestitution disease involving the innate and adaptive response. Clin Infect Dis 2000, 30:882-92.

28. Wislez M, Bergot E, Antoine M, Parrot A, Carette MF, Mayaud C, Cadranel J: Acute respiratory failure following HAART introduction in patients treated for Pneumocystis carinii pneumonia. Am J Respir Crit Care Med 200I, 164:847-5I.

29. Dean GL, Williams DI, Churchill DR, Fisher MJ: Transient clinical deterioration in HIV patients with Pneumocystis carini pneumonia after starting highly active antiretroviral therapy: another case of immune restoration inflammatory syndrome. Am J Respir Crit Care Med 2002, I65:1670.

30. Barry SM, Lipman MC, Deery AR, Johnson MA, Janossy G: Immune reconstitution pneumonitis following Pneumocystis carinii pneumonia in HIV-infected subjects. HIV Med 2002, 3:207-I I.

31. Koval CE, Gigliotti F, Nevins D, Demeter LM: Immune reconstitution syndrome after successful treatment of Pneumocystis carinii pneumonia in a man with human immunodeficiency virus type I infection. Clin Infect Dis 2002, 35:49I-3.

32. Cheng VC, Hung IF, Wu AK, Tang BS, Chu CM, Yuen KY: Lymphocyte surge as a marker for immunorestitution caused by Pneumocystis carinii pneumonia in non-HIV immunosuppressed hosts. Eur J Clin Microbiol Infect Dis 2004, 23:5 I 2-4.

33. Cheng VC, Yuen KY, Wong SS, Woo PC, Ho PL, Lee R, Chan RM: Immunorestitution diseases in patients not infected with HIV. Eur J Clin Microbiol Infect Dis 200I, 20:402-6.

34. Cheng VC, Woo PC, Lau SK, Cheung CH, Yung RW, Yam LY, Yuen $\mathrm{KY}$ : Peripartum tuberculosis as a form of immunorestitution disease. Eur / Clin Microbiol Infect Dis 2003, 22:313-7.

35. Cheng VC, Ho PL, Lee RA, Chan KS, Chan KK, Woo PC, Lau SK, Yuen KY: Clinical spectrum of paradoxical deterioration during antituberculosis therapy in non-HIV-infected patients. Eur J Clin Microbiol Infect Dis 2002, 21 :803-9.

36. Cheng VC, Yam WC, Woo PC, Lau SK, Hung IF, Wong SP, Cheung WC, Yuen KY: Risk factors for development of paradoxical response during antituberculosis therapy in HIV-negative patients. Eur J Clin Microbiol Infect Dis 2003, 22:597-602.

37. Mansharamani NG, Balachandran D, Vernovsky I, Garland R, Kozie $\mathrm{H}$ : Peripheral blood CD4 + T-lymphocyte counts during Pneumocystis carinii pneumonia in immunocompromised patients without HIV infection. Chest 2000, I I 8:7| 2-20.

38. Nevez G, Raccurt C, Vincent P, Jounieaux V, Dei-Cas E: Pulmonary colonization with Pneumocystis carinii in human immunodeficiency virus-negative patients: assessing risk with blood CD4+ T cell counts. Clin Infect Dis 1999, 29:1331-2.

39. Sing A, Trebesius K, Roggenkamp A, Russmann H, Tybus K, Pfaff $F$, Bogner JR, Emminger C, Heesemann J: Evaluation of diagnostic value and epidemiological implications of PCR for Pneumocystis carinii in different immunosuppressed and immunocompetent patient groups. J Clin Microbiol 2000, 38: I46I-7.

40. Rabodonirina M, Cotte L, Boibieux A, Kaiser K, Mayencon M Raffenot D, Trepo C, Peyramond D, Picot S: Detection of Pneumocystis carinii DNA in blood specimens from human immunodeficiency virus-infected patients by nested PCR. J Clin Microbiol I999, 37:|27-3I.

4I. Ribes JA, Limper AH, Espy MJ, Smith TF: PCR detection of Pneumocystis carinii in bronchoalveolar lavage specimens: analysis of sensitivity and specificity. J Clin Microbiol 1997, 35:830-5.

\section{Pre-publication history}

The pre-publication history for this paper can be accessed here: http://www.biomedcentral.com/1471-2334/4/57/prepub
Publish with Biomed Central and every scientist can read your work free of charge

"BioMed Central will be the most significant development for disseminating the results of biomedical research in our lifetime. "

Sir Paul Nurse, Cancer Research UK

Your research papers will be:

- available free of charge to the entire biomedical community

- peer reviewed and published immediately upon acceptance

- cited in PubMed and archived on PubMed Central

- yours - you keep the copyright
Biomedcentral 